\title{
ASPECTOS POLÊMICOS DO CONTRATO DE EMPREITADA - ANÁLISE FUNDAMENTADA NO DIREITO COMPARADO
}

Rodrigo Alves Zaparoli Telma Djanira Maciel

\section{RESUMO}

O presente artigo almeja proporcionar uma análise sobre os principais aspectos inerentes ao contrato de empreitada, abordagem esta que englobará um estudo comparado sobre as diferenças e semelhanças que envolvem o contrato de empreitada nas legislações brasileira, argentina, mexicana e portuguesa.

Com o escopo de atingirmos o objetivo proposto, nos pautaremos na legislação civil em vigor em cada um dos países utilizados como parâmetro para o estudo, de modo a propiciar uma análise dinâmica, comparativa e objetiva do tema.

Portanto, nos moldes do que restou exposto, almejamos com este trabalho proporcionar uma análise comparada do contrato de empreitada levandose em consideração as principais diferenças e semelhanças existentes na legislação estrangeira. 
Palavras - chave: Contrato de empreitada. Direito comparado. Legislação argentina. Legislação mexicana. Legislação portuguesa.

\section{INTRODUÇÃO}

Caracterizada como modalidade de contrato em nosso ordenamento, a empreitada também possui posição de destaque, não só na legislação lusitana, que contribuiu em permear as bases de nosso ordenamento, mas também na argentina e mexicana, que de forma inegável descendem das tradições latinas e possuem raízes no direito romano.

O presente artigo almeja expor o conceito do instituto e propiciar o estudo comparado através de uma abordagem célere às mencionadas legislações, ocasião em que serão analisadas suas semelhanças e diferenças desde os respectivos conceitos, passando pelas partes envolvidas no contrato, objeto, riscos, remuneração, forma de cumprimento da obrigação, hipóteses de rejeição da obra e sua rescisão.

Destacam-se, ainda, a análise sobre as questões relacionadas ao reajuste e redução de preço nas obras de empreitada. Além de comentários acerca da subempreitada e os direitos e deveres dela decorrentes.

Enfim, cuida-se de análise, com a pretensão não exaustiva de possibilitar o estudo comparado das legislações em apreço.

\section{ORIGEM HISTÓRICA DA EMPREITADA}

O contrato de empreitada revela-se oriundo do direito romano, mais especificamente dos institutos da locatio conductio operis, ou ainda, locatio operis faciendi.

Vale ressaltar que a locatio conductio por si só, corresponde ao contrato de locação de empreitada, que almejava regulamentar a atividade dos indivíduos que se comprometiam a locar sua mão de obra, locação esta que seria remunerada através da entrega de certo preço.

Por sua vez, a locatio operis faciendi, mantém vínculo com a empreitada contemporânea, vez que correspondia à confecção de obra determinada, na qual o indivíduo, na época denominado conductor, as- 
sumia a obrigação de edificar certo objeto previamente ajustado com seu dono, que era denominado locator.

Insta salientar que a mão de obra fornecida pelo conductor em benefício do locator era prestada mediante a promessa de pagamento de preço certo, destacando-se o fato de que os materiais a serem utilizados no curso da empreitada eram fornecidos pelo próprio locator, que os disponibilizava mediante o pagamento de aluguel.

Portanto, o contrato romano da locatio operis faciendi equivaleria à modalidade contratual que deu origem à empreitada existente na legislação brasileira, destacando-se que o contrato descrito apresentava como partes o conductor que corresponderia ao empreiteiro da legislação pátria e o locator, que manteria relação com a figura do dono da obra.

Cumpre esclarecer que a herança romana narrada até o momento foi alvo de análise de grande parte da doutrina, nos moldes do que comprovam as lições ofertadas por Carlos Roberto Gonçalves, ensinamentos estes que seguem abaixo transcritos:

"Empreitada (locatio operis) é contrato em que uma das partes (o empreiteiro), mediante remuneração a ser paga pelo outro contraente (o dono da obra), obriga-se a realizar determinada obra, pessoalmente ou por meio de terceiros, de acordo com as instruções deste e sem relação de subordinação". 390

Diante das considerações expostas, resta devidamente analisada a origem histórica da empreitada, instituto jurídico que possui seus princípios basilares enraizados no direito romano.

\section{CONTRATO DE EMPREITADA}

Superado o estudo inerente à origem histórica da empreitada, passa-se a discorrer sobre a definição do instituto, que consiste na modalidade contratual em que uma das partes denominada empreiteiro se obriga a entregar pessoalmente ou através de terceiros, obra material ou intelectual concluída nos termos previstos pelo instrumento contratual, entrega esta que se dará mediante o pagamento de certa retribuição, ou seja, o principal objetivo da empreitada é a entrega da obra contratada, tratando-

\footnotetext{
${ }^{390}$ GONÇALVES, Carlos Roberto. Direito civil brasileiro: contratos e atos unilaterais. 4. ed., rev. e atual. São Paulo: Saraiva, 2007, p. 343.
} 
se, portanto, de obrigação de resultado, não havendo vínculo empregatício entre as partes.

Ao discorrer sobre a obrigação de resultado acima descrita apresentam-se como relevantes as lições prestadas por Maria Helena Diniz, que, em sua obra, declara que a "empreitada contém uma obrigação de resultado, por ter em vista a obra executada, de modo que só será devida a remuneração se a obra for realmente feita". 391

Ante as considerações realizadas, vale observar que a obrigação do empreiteiro não se estende somente a entregar a obra, mas sim em executá-la da melhor maneira possível, de modo a garantir sua solidez e aptidão para atender aos objetivos para os quais foi projetada.

Logo, não basta ao empreiteiro confeccionar o objeto contratado, mas sim desenvolvê-lo em respeito às normas técnicas existentes, de modo que o bem resultado da empreitada possua a qualidade, solidez e funcionalidade dele esperado. Portanto, o contrato de empreitada exige não apenas a entrega do objeto, mas também que o bem contratado apresente todas as características almejadas pelo dono da obra.

Com o escopo de findar a conceituação do instituto, relevante a exposição do conceito formulado por César Fiuza, que estabelece:

"Empreitada ou locação de obra é o contrato pelo qual um dos contratantes se obriga, sem subordinação ou dependência, e sem qualquer vínculo empregatício, a entregar ao outro o resultado de sua atividade, pessoalmente ou por interposta pessoa, com material próprio ou não, mediante remuneração determinada ou proporcional ao trabalho executado". 392

Diante das informações prestadas, constata-se que o contrato de empreitada possui como características o fato de ser: bilateral, oneroso, consensual e, como regra, comutativo, pois eventualmente pode vir a ser aleatório.

É relevante expor que além das características descritas, Orlando Gomes ensina que se trata de um contrato de execução única e, eventualmente de duração, "como quando o empreiteiro se obriga a produzir,

\footnotetext{
${ }^{391}$ DINIZ, Maria Helena. Curso de direito civil brasileiro: responsabilidade civil. 20 . ed. rev. e atual. São Paulo: Saraiva, 2006.7 v, p.338.

${ }^{392}$ FIUZA, César. Direito civil: curso completo. $7^{\mathrm{a}}$. ed., rev., atual. e ampl. de acordo com o código civil de 2002. Belo Horizonte: Del Rey, 2003, p.441.
} 
repetidamente, a obra, executando-a em série, por unidades autônomas". 393

Por sua vez, necessário também se faz informar, que no âmbito jurídico atual a empreitada encontra-se prevista no Livro I, Título V, Capítulo VIII da Parte Especial do Código Civil de 2002.

Superada a breve introdução sobre o instituto jurídico em análise, passar-se-á o tópico seguinte a discorrer sobre o contrato de empreitada de modo mais abrangente, seguindo por ordem cronológica a disposição dos artigos pertinentes ao tema na legislação brasileira (arts. 610 a 626) reportando de maneira célere às legislações eleitas (argentina, mexicana e portuguesa) com o objetivo de propiciar o estudo comparado proposto.

\section{CONTRATO DE EMPREITADA SOB A ÉGIDE DO DIREITO COMPARADO}

Ao iniciar a análise comparativa do instituto poder-se-ia elencar como primeira diferença o tratamento que o legislador de cada país atribuiu ao tema em debate.

Destaca-se que para o desenvolvimento do presente artigo foi utilizado o novo Código Civil argentino, que desde sua vigência, que se operou em 2015, passou a empregar um critério diferenciado da legislação revogada, que utilizava o termo locação para definir tal modalidade contratual.

A atual legislação argentina, que versa sobre o tema em seu novo Código Civil, eliminou a expressão locación de obras y servicios, sendo que através de 29 artigos (arts. 1251/1279), e com melhor técnica legislativa que a existente na codificação anterior (Código de Vélez Sarsfield), segue agora o critério dos denominados códigos decimonónicos (construídos no século XIX) $^{394}$, passando a tratar a matéria apenas como contrato de obra o de servicios.

\footnotetext{
${ }^{393}$ GOMES, Orlando. Contratos. 26a . ed. Rio de Janeiro: Forense, 2008, p.366.

${ }^{394}$ Caramelo, Gustavo, Código Civil y Comercial de la Nación Comentado / Gustavo Caramelo ;Sebastián Picasso ; Marisa Herrera. - 1a ed. - Ciudad Autónoma de Buenos Aires : Infojus, 2015, p. 01 - 02.
} 
O capítulo descrito (sexto) divide o assunto em três seções: a primeira, referente às disposições comuns a obras e serviços; a segunda, destinada às disposições especiais para as obras e a terceira, referente às normas especiais correspondentes aos serviços, sem deixar de mencionar a aplicação das normas protetivas ao consumidor, desde que enquadradas no artigo 1093 do Código Argentino.

Nesse sentido é preciso mencionar, que com a extinção da expressão locação ao contrato de obra, a atual dicção adotada pela lei argentina, diga-se, contrato de obras e serviços, revela-se semelhante à empregada nos códigos brasileiro, português e mexicano.

Quanto às características básicas inerentes ao contrato de empreitada, constata-se que essas não possuem grandes divergências entre as codificações objeto de comparação, já que apesar de estarem presentes diferenças no vernáculo, em todas as legislações objeto de análise existe a figura do empreiteiro, que no caso é aquele que executará a obra, cabendo a ele sua fiscalização e a responsabilidade pelos riscos dela provenientes.

Além do mais, as codificações alvo de estudo também arrolam a figura do dono da obra, que consistirá na pessoa que contrata os serviços do empreiteiro mediante certa remuneração previamente estabelecida.

Assim, preliminarmente, conclui-se que o conceito do instituto jurídico, bem como as partes envolvidas no contrato, não apresentam diferenças além daquelas relacionadas ao vernáculo adotado por cada país.

A distinção atrelada ao vernáculo possui fundamento, pois enquanto no Brasil e Portugal, utiliza-se do termo empreiteiro e dono da obra, na Argentina e México, empregam-se as palavras comitente e dueño de la obra.

Cumpre salientar ainda que, em todas as legislações analisadas, encontram-se presentes a figura da empreitada de lavor ou de mão de obra e de materiais, sem que ocorra divergência entre os institutos praticados nos países alvo de comparação.

Vale ressaltar que a empreitada de lavor caracteriza-se como aquela em que o empreiteiro fornece seus conhecimentos como construtor, edificando a obra, sem ter a responsabilidade de fornecer qualquer material.

Por outro lado, a empreitada de materiais configura-se pelo fato do empreiteiro, além de prestar sua mão de obra, fornecer os materiais necessários para que se edifique o objeto do contrato. 
Ao analisar o que fora exposto, necessária se faz uma interrupção, pois é evidenciada diferença apurada entre as legislações, já que enquanto na legislação brasileira (art. $610, \S 1^{\circ}$ ) nos casos em que não existir estipulação contratual, ou ainda, previsão legal, a regra é que seja adotada a modalidade de lavor; nas legislações portuguesa (art. 1.210, 1) e mexicana (art. 2.616), estipula-se que os materiais e utensílios necessários à execução da obra deverão ser fornecidos pelo empreiteiro, salvo convenção ou uso em contrário.

Por sua vez, o Código Civil Argentino não se posiciona sobre qual das duas modalidades será adotada como regra, determinando através do artigo 1.262, que será facultado às partes contratantes optar pela modalidade que melhor lhes convir, porém, se nada foi acordado, presumir-se-á que será fornecedor dos materiais o empreiteiro.

Superada a questão inerente à espécie de empreitada a ser adotada, é importante abordar que o objeto do contrato será semelhante em todos os países, pois englobará qualquer espécie de produção, ou seja, não envolverá apenas as edificações relacionadas a bens imóveis, mas também as criações artísticas, intelectuais e de bens móveis, questão que se revela evidente com a leitura do artigo 1.212, 1 do Código Civil Português, que dispõe exclusivamente sobre a construção de coisa móvel e a consequente transferência de propriedade da coisa.

Ainda no tocante ao tratamento fornecido pela legislação estrangeira nos casos em que se tratar de bem móvel o objeto do contrato de empreitada, relevantes se demonstram as previsões existentes na codificação mexicana, que em seu dispositivo 2.618 versa sobre a obrigatoriedade de se formular contrato por escrito quando o valor da coisa móvel superar cem pesos, destacando-se também o artigo 2.644, que prevê o direito de retenção inerente ao empreiteiro quando não for realizado o pagamento por parte do dono da obra.

Ante as considerações expostas acima, apesar de concluir que a empreitada poderá ter por objeto bens móveis, apuramos que a faculdade descrita recebe maior tutela por parte das codificações portuguesa e mexicana.

Analisadas as questões inerentes ao objeto do contrato, bem como às partes envolvidas, iniciar-se-á o estudo acerca da responsabilidade civil prevista pelas legislações alvo de comparação. 
Para tanto, o primeiro aspecto a ser abordado, será o da obrigação assumida pelo empreiteiro em relação ao dono da obra, essa que se trata de obrigação de resultado, nos moldes do que já fora abordado.

Dessa forma, por tratar-se de obrigação de resultado, o empreiteiro deverá respeitar integralmente as previsões contratuais, fazendo com que o objeto da empreitada venha a atender às expectativas para o qual foi encomendado.

Com relação aos dispositivos legais inerentes ao tema, destacam-se no Código Civil Brasileiro os artigos 611 e 612 que possuem vínculo do ponto de vista do direito comparado com os dispositivos $1.256 \mathrm{e}$ seguintes da legislação argentina, 2.617 da mexicana e 1.228 do Código Civil Português.

Cumpre esclarecer que o caput do artigo 611 do Código Civil Brasileiro prevê a hipótese em que o empreiteiro, além de prestar seus serviços relacionados à mão de obra especializada, também fornecerá os materiais que serão empregados para a confecção do objeto contratado. Destaca-se ainda, que o dispositivo descrito preceitua que os riscos até a entrega da obra correrão por conta do empreiteiro, exceto se o dono da obra estiver em mora quanto ao recebimento do objeto da contratação, previsão que se assemelha ao artigo 1.268 da legislação argentina.

Quanto aos riscos provenientes da empreitada, cabe discorrer ainda sobre a previsão fornecida pelo caput do artigo 612 do Código Civil Brasileiro, que estabelece a hipótese em que o empreiteiro restringe-se apenas ao fornecimento da mão de obra, circunstância em que todos os riscos, exceto aqueles gerados por culpa do profissional supracitado, correrão por conta do dono da obra.

Portanto, o dispositivo acima elencado estabelece implicitamente que o empreiteiro será responsável inclusive pelos demais funcionários que estiverem sob a sua supervisão no curso do contrato, responsabilidade esta que é prevista de maneira expressa pelo legislador mexicano através do artigo 2.642 de seu Código Civil.

Ao prosseguir com a ordem cronológica adotada, observamos que a legislação brasileira prevê em seu artigo 613, que nos casos em que a empreitada for de lavor e a coisa vier a perecer antes da entrega, sem que seja caracterizada mora do dono da obra, ou ainda, culpa do empreiteiro, este perderá a contraprestação caso não consiga demonstrar que a perda provém de defeitos de qualidade ou quantidade inerentes ao material fornecido pelo dono da obra, que em tempo havia sido reclamado, 
norma que apresenta disposição similar na codificação argentina (arts. 1.256 e 1.268).

Em seguida, o Código Civil Brasileiro passa a versar através do caput do artigo 614 sobre a remuneração do contrato de empreitada nos casos em que a obra constitui-se de partes distintas, ou ainda, que possa se determinar por medida, hipótese em que será facultado ao empreiteiro exigir o pagamento do preço proporcional ao percentual da obra que fora executado.

Vale ressaltar que a previsão legal acima abordada também é amparada pelas codificações alvo de nosso estudo comparado, nos moldes do que atestam os artigos 1.266 do Código Civil Argentino e 2.630 da legislação mexicana.

Dessa maneira, ao analisar o que fora exposto até o momento, pode-se presumir que, em regra, o adimplemento da contraprestação pelo dono da obra deverá ocorrer quando da entrega do objeto do contrato de empreitada, disposição esta que não é expressamente arrolada por nossa legislação, ao contrário do que ocorre nas codificações mexicana (art. 2.625) e portuguesa (art. 1.211,2).

Em complementação ao disposto no caput do artigo 614, o legislador brasileiro inseriu o $\S 1^{\circ}$, que estabelece que tudo o que se pagou no curso da relação jurídica se presume verificado, e o $\$ 2^{\circ}$, que se pressupõe como verificado aquilo que fora medido e que dentro do prazo de 30 (trinta) dias contados da medição não fora alvo de denúncias relacionadas a possíveis vícios e defeitos.

Neste momento, cumpre atentar para o surgimento de uma divergência importante entre as legislações em análise, vez que o Código Civil Mexicano através de seu artigo 2.631 se contrapõe à previsão fornecida pelos parágrafos do artigo 614 da legislação brasileira.

A diferença supracitada possui fulcro no fato de que para os mexicanos, apesar de se presumir aprovada e recebida pelo dono da obra a parte que fora alvo de adimplemento, não existe um lapso temporal específico para que ocorra alguma espécie de denúncia, circunstância que se revela na codificação brasileira.

Superado o apontamento descrito tem início a análise sobre as hipóteses de rejeição do objeto contratual pelo dono da obra, bem como dos casos em que poderá ocorrer o abatimento no preço pago ao empreiteiro. 
Quanto ao tema acima ventilado, o artigo 615 do Código Civil Brasileiro estabelece que o dono da obra deverá receber o objeto do contrato na hipótese desse ter sido entregue de acordo com o que fora ajustado contratualmente.

Destaca-se ainda que o artigo 615 versa sobre as hipóteses que facultam ao dono da obra rejeitá-la, circunstância que ocorrerá quando o empreiteiro não cumprir os projetos que haviam sido contratados, ou ainda, quando se afastar das regras técnicas inerentes aos trabalhos da mesma natureza.

Assim, constata-se que em relação ao dono da obra emana a obrigação de receber o objeto contratual na forma que fora ajustada, ou seja, o dono da obra não poderá arbitrariamente enjeitar o objeto contratado.

Por sua vez, ao discorrer sobre o não cumprimento ao que fora estipulado em contrato, deve-se tornar claro que se o descumprimento ao projeto foi realizado de má-fé, ou de forma culposa, acaba por gerar a obrigação por parte do empreiteiro de reparar os prejuízos suportados pelo dono da obra, ou seja, emana de forma incontroversa o dever de reparação.

As conclusões acima obtidas apresentam ainda maior fundamentação se as interpretarmos em conjunto com o artigo 616 do Código Civil Brasileiro, dispositivo que admite a hipótese de que ao observar-se o caso concreto, ao invés do dono da obra enjeitar o objeto do contrato, poderá vir a recebê-lo com abatimento no valor a ser pago ao empreiteiro. Por sua vez, cabe ao empreiteiro, consentir com o abatimento se não quiser ver rejeitado o objeto por ele edificado.

Ao dissertar sobre as tutelas prestadas pelos dispositivos em análise, Carlos Roberto Gonçalves leciona que se trata de:

"uma responsabilidade decorrente não só dos conhecimentos técnicos, mas também das noções de estética e arte. Fundado nessa responsabilidade é que o Código Civil autoriza o cliente a rejeitar a obra imperfeita ou defeituosa (art. 615) ou a recebê-la com abatimento no preço, se assim lhe convier (art. 616)". 395

Quanto à análise legislativa comparada, necessário se faz informar que o Código Civil Português em seus artigos 1.217, 2 e 1.221, 1

\footnotetext{
395 GONÇALVES, Carlos Roberto. Responsabilidade civil. $8^{\text {a }}$. ed. rev. de acordo com o novo Código Civil. São Paulo: Saraiva, 2003, p. 411.
} 
também faculta o direito do dono da obra a recusá-la, sem prejuízo de indenização por força dos prejuízos suportados, destacando-se inclusive a peculiaridade (art. 1.221, 1) de que se os defeitos não puderem ser suprimidos poderá o dono da obra exigir a nova construção e posterior entrega do objeto contratual.

Destaca-se ainda na legislação portuguesa a previsão fornecida pelo artigo subsequente (art. 1.222), que trata da redução do preço e resolução do contrato se os defeitos tornarem a obra inadequada à finalidade a que se destina, hipóteses que serão caracterizadas sempre que os defeitos não puderem ser eliminados, ou ainda, quando a obra não puder ser reconstruída. Por fim, destaca-se também que o legislador português através do artigo 1.223 tornou claro que o exercício dos direitos arrolados nos artigos antecedentes (art. 1.218 a 1.222) não excluirá a possibilidade de a parte prejudicada pleitear o direito à justa indenização pelos prejuízos suportados.

Ainda no tocante ao estudo comparado do Código Civil Português, é dever destacar que esse estipula em seu artigo 1.224 os prazos de caducidade para o exercício dos direitos de eliminação dos defeitos, bem como de redução do preço ajustado, e da resolução ou indenização vinculadas ao contrato de empreitada, declarando através do artigo 1.224,1 que os direitos descritos caducarão se não forem exercidos dentro do prazo de 01 (um) ano contado da recusa da aceitação da obra, ou ainda, da aceitação com reserva.

O dispositivo acima analisado é complementado pelo artigo $1.224,2$, que preceitua que na hipótese dos defeitos serem desconhecidos pelo dono da obra, referido prazo de caducidade contar-se-á a partir da denúncia do defeito, destacando-se ao final que tais direitos previstos pelo artigo 1.224 não poderão ser exercitados se decorrido o prazo de 02 (dois) anos contados da entrega do objeto contratado.

Cumpre destacar quanto à existência de defeitos ocultos, que o Código Civil Argentino também disserta sobre a matéria, vez que em seu artigo 1.272, b, faz remissão ao artigo 1.054, que determina que nos casos em que forem constatados defeitos ocultos no objeto proveniente da empreitada, o dono da obra terá 60 (sessenta) dias para denunciá-los, prazo este a ser contado desde a descoberta do defeito.

Ao prosseguir com a ordem cronológica proposta, cumpre observar que o legislador brasileiro também se preocupou em imputar ao empreiteiro a responsabilidade inerente ao uso devido dos materiais for- 
necidos pelo dono da obra nos casos de empreitada de lavor; isto ocorre, pois caso haja desperdício de materiais pela imperícia, negligência, ou ainda, culpa do empreiteiro, este deverá ressarcir o dono da obra (art. 617).

Maria Helena Diniz ao discorrer sobre o artigo em análise declara que esse versa sobre a responsabilidade do empreiteiro de responder "pelo pagamento dos materiais que recebeu, se por negligência ou imperícia os inutilizar". 396

Frise-se que no tocante à tutela fornecida pelo dispositivo objeto do presente estudo (art. 617), não foi possível observar expressamente nas demais legislações a mesma previsão, apesar de que através da leitura dos textos legislativos alvo de comparação é possível constatar implicitamente que a responsabilidade descrita também será aplicada.

Superado o questionamento descrito, tem início o estudo sobre a tutela fornecida pelo artigo 618 do Código Civil Brasileiro, destacando-se que o presente dispositivo se revela como o mais importante no tocante à análise do tema sob a égide do direito comparado.

A informação supracitada se fundamenta no fato de que o caput do artigo 618 estabelece a responsabilidade inerente ao empreiteiro de responder pelo prazo irredutível de 05 (cinco) anos pela segurança e solidez, bem como em razão dos materiais empregados na empreitada que teve por objeto um edifício, ou ainda, outra construção considerada de vulto.

Segundo Maria Helena Diniz:

O empreiteiro, para os efeitos do art. 618 do Código Civil, é o construtor, engenheiro, arquiteto, habilitado legalmente ao exercício da profissão, ou pessoa jurídica autorizada a construir. Em suma, é o profissional da construção civil. ${ }^{397}$

Além do mais, cumpre destacar que o parágrafo único do artigo 618 vem complementar a tutela legal ao determinar que decairá do direito

\footnotetext{
${ }^{396}$ DINIZ, Maria Helena. Curso de direito civil brasileiro: responsabilidade civil. 20 . ed. rev. e atual. São Paulo: Saraiva, 2006.7 v, p. 338.

${ }^{397}$ DINIZ, Maria Helena. Curso de direito civil brasileiro: responsabilidade civil. $20^{\mathrm{a}}$. ed. rev. e atual. São Paulo: Saraiva, 2006. 7 v, p. 331.
} 
assegurado no caput o dono da obra que não propor a devida ação em face do empreiteiro no prazo de 180 (cento e oitenta) dias contados do surgimento do vício ou defeito.

Assim, observa-se que o dispositivo objeto de análise versa sobre uma responsabilidade de caráter excepcional, pois em regra, ao receber uma coisa encomendada, a parte que entregou o objeto contratado está liberada de qualquer ônus, logo, ao contrário do que é previsto para diversas outras modalidades contratuais, no contrato descrito, o empreiteiro, mesmo depois de entregue a obra, permanecerá responsável por sua solidez e segurança, questão que envolverá inclusive o solo em que foi erguida a edificação.

Indispensável frisar que o prazo descrito, não poderá ser modificado, mesmo que tal mudança venha a ser expressa no instrumento contratual; isso ocorre porque esse lapso temporal não foi estabelecido legalmente apenas para atender aos interesses do dono da obra, mas sim de toda a sociedade. Portanto, o prazo quinquenal é imperativo e de ordem pública, não podendo o empreiteiro dele se eximir ou reduzir sua amplitude.

Ante as considerações realizadas, concluímos que a responsabilidade inerente aos empreiteiros persistirá não só em relação ao dono da obra, mas também perante as demais pessoas que o sucederem na propriedade, pois conforme ensina Carlos Roberto Gonçalves, a "alienação não pode ser causa de isenção de responsabilidade do construtor pela solidez e segurança da obra, que é de natureza legal". 398

Superada a análise atrelada à legislação pátria, iniciar-se-á o estudo do ponto de vista do direito comparado, cuja importância também se demonstra relevante pelo fato de que todas as outras codificações alvo de comparação (Argentina, México e Portugal) apresentam disposições distintas da brasileira, bem como diferentes entre si.

Com o objetivo de justificar o que fora alegado, tem início a análise sob o viés da interpretação do Código Civil Argentino, que em seu artigo 1.273 prevê, como regra geral, a responsabilidade dos empreiteiros de responderem pela segurança e solidez de edifícios ou imóveis destinados a longa duração, logo, constata-se que se trata de tutela semelhante à brasileira, com a exceção de que, para a legislação argentina, o

\footnotetext{
398 GONÇALVES, Carlos Roberto. Responsabilidade civil. $8^{\text {a }}$. ed. rev. de acordo com o novo Código Civil. São Paulo: Saraiva, 2003, p. 418.
} 
prazo de garantia perdurará por 10 (dez) anos, nos moldes do que estabelece o artigo 1.275 da codificação.

Previa o anterior Código de Vélez Sársfield que os empreiteiros construtores elencados pela legislação argentina seriam responsabilizados ainda pelo descumprimento às disposições municipais ou policiais, bem como por todo e qualquer dano que venha a causar prejuízos a vizinhos (art. 1.647). O atual Código mantém a respectiva interpretação em seu artigo 1.277. Esta norma contempla um rol mais amplo de sorte a incluir os subcontratados e os profissionais que intervêm em uma construção, além de estipular o cumprimento de normas administrativas, como por exemplo, os denominados códigos urbanos.

Em complementação ao tema, importante se faz ressaltar que outra divergência existe entre a norma brasileira e a argentina, já que a segunda estabelece que o prazo prescricional será de 01 (um) ano para a prática do exercício do mencionado direito, esclarecendo de forma objetiva que as partes não poderão dispor dessa prerrogativa legal, que se aplicará inclusive ao diretor da obra e seu projetista dependendo das circunstâncias observadas.

Superada a análise inerente à legislação argentina, tem início o estudo sobre a tutela legislativa fornecida pelo Código Civil Mexicano, que disserta sobre o tema em seus artigos 2.634, 2.642 e 2.645.

Vale ressaltar que a legislação mexicana não é taxativa como a brasileira e a argentina, que estabeleceram prazos fixos e amplos para obras consideradas de vulto.

A afirmação supracitada fundamenta-se no fato de que o Código Civil Mexicano apenas se reserva a determinar que o empreiteiro é responsável pelos defeitos e vícios que vierem a ser caracterizados no objeto do contrato de empreitada, dispondo que referida responsabilidade recai sobre os materiais empregados e o solo utilizado para abrigar o bem, a não ser que o empreiteiro tenha alertado o dono da obra expressamente sobre tais vícios e defeitos inerentes ao solo e materiais (art. 2.634).

Ainda com relação à legislação mexicana é verificado que essa preceitua que o empreiteiro será responsabilizado pela atividade de todas as pessoas que participarem da confecção do objeto do contrato (art. 2.642), estabelecendo inclusive que os empreiteiros construtores serão responsáveis pelo descumprimento das normas municipais ou de polícia, bem como por todos os danos que vierem a ser causados aos vizinhos (art. 2.645). 
Por fim, ainda no tocante à análise comparativa do artigo 618 da norma brasileira, necessário discorrer sobre o Código Civil Português, que abarca a matéria em seu artigo 1.225.

Insta salientar que a codificação portuguesa, de forma semelhante à brasileira, preceitua que a garantia vinculada às obras de vulto será de 05 (cinco) anos, arrolando, contudo, que poderá existir prazo de garantia a ser convencionado entre os contratantes.

Quanto à contagem do lapso temporal acima exposto, o legislador português estabeleceu que seu início ocorrerá a partir da entrega do bem. Por sua vez, no tocante ao prazo para a denúncia dos defeitos e vícios, essa deverá ser efetuada dentro do prazo de 01 (um) ano e a indenização deverá ser pleiteada no ano seguinte à realização da denúncia (art. $1.225,2)$.

Ao final, julgamos relevante destacar que o Código Civil Português faculta ao empreiteiro o exercício do direito de regresso em face do subempreiteiro, faculdade esta que caducará se não ocorrer a comunicação da denúncia pelo empreiteiro ao subempreiteiro dentro do prazo de 30 (trinta) dias contados de sua recepção (art. 1.226).

Expostas as considerações acima, é possível passar à análise dos artigos 619 e 620 do Código Civil Brasileiro, que versam sobre a remuneração e o reajustamento do contrato de empreitada.

Cumpre esclarecer que o caput do artigo 619 do Código Civil Brasileiro discorre sobre a remuneração nos contratos de empreitada, que em regra será sem reajustamento, a não ser que ocorram modificações no projeto resultantes de instruções escritas pelo dono da obra.

Importante também se demonstrar a previsão de que ainda que não tenha se perpetuado a autorização por escrito, o dono da obra será obrigado a adimplir em benefício do empreiteiro as majorações, nos moldes do que fora arbitrado, nos casos em que presente na obra, por reiteradas visitas, não podia ignorar o que estava ocorrendo, e nunca protestou (parágrafo único do artigo 619).

Em complementação ao que fora exposto, necessário se faz discorrer sobre a possibilidade do contrato de empreitada possuir cláusulas de reajustamento, estas que segundo Orlando Gomes são "Perfeitamente 
lícitas, é necessário, contudo, que o direito do empreiteiro ao reajustamento seja expressamente consignado no contrato". 399

Ao versar sobre a possibilidade da adoção de cláusulas que permitam o reajuste dos valores a serem adimplidos, Caio Mário da Silva Pereira leciona:

empreitada com reajustamento é a que contém cláusula permissiva da variação do preço em consequência do aumento ou diminuição valorativa de seus componentes, como sejam a mão de obra e os materiais. Nas épocas de instabilidade, é frequentemente convencionada, pondo o empreiteiro coberto das súbitas oscilações do mercado e defendendo-o do injusto locupletamento do dono da obra; mas, por outro lado, evita os orçamentos demasiadamente elevados com os quais, a pretexto de defender-se de preços instáveis, o contrato permite que as partes, periodicamente ou à vista dos eventos determinantes de alterações, revejam a retribuição contratada, atualizando-a. ${ }^{400}$

Por fim, ainda com relação à remuneração do contrato em análise, destaca-se a possibilidade da empreitada ser ajustada por preço de custo, esta que segundo Caio Mário da Silva Pereira "é aquela em que o empreiteiro fica obrigado a realizar o trabalho, sob sua responsabilidade, com fornecimento de materiais e pagamento de mão de obra, mediante reembolso do despendido, acrescido do lucro assegurado". 401

Do ponto de vista do direito comparado, relevante se faz informar que a legislação argentina em seu artigo 1.255 prescreve a impossibilidade de se reajustar o preço quando a empreitada for entabulada por preço certo, medida esta que faz com que os contratantes exerçam grande cautela quando da elaboração do contrato, para que dessa forma prejuízos possam ser evitados.

\footnotetext{
${ }^{399}$ GOMES, Orlando. Contratos. 26 . ed. Rio de Janeiro: Forense, 2008, p.368.

400 PEREIRA, Caio Mário da Silva. Instituições de direito civil: contratos. $12^{\mathrm{a}}$. ed., rev. e atual. Rio de Janeiro: Forense, 2007.6 v., p.317.

${ }^{401}$ Idem, p.318.
} 
Por sua vez, o Código Civil Mexicano, através de seu dispositivo 2.626 , também estabelece a impossibilidade de reajustar a remuneração da empreitada pactuada por preço determinado. Entretanto, através do artigo subsequente (art. 2.627) o legislador efetua a mesma ressalva abordada pela norma brasileira, pois determina que a modificação do preço poderá ocorrer desde que as alterações no projeto tenham sido resultantes de instruções escritas pelo dono da obra, essas que deverão inclusive relacionar-se expressamente à questão do preço a ser reajustado.

Quanto ao tema, importantes também se revelam as previsões inerentes à legislação portuguesa, já que o Código Civil Português, em seu artigo 1.214, 3, estabelece que nas hipóteses em que for fixado preço determinado para a empreitada e não tiver ocorrido por escrito a alteração do projeto estipulando o reajuste do preço, o empreiteiro apenas poderá requerer indenização equivalente ao enriquecimento contraído pelo dono da obra.

Superados os comentários atrelados ao artigo 619 da legislação pátria, nota-se que o artigo 620 do Código Civil Brasileiro, basicamente prevê a revisão do preço a ser adimplido pelo dono da obra todas as vezes em que ocorrer a redução no preço do material ou da mão de obra superior a 1/10 (um décimo) do preço ajustado.

Em relação à análise comparativa do dispositivo acima descrito, necessário se faz informar que a legislação portuguesa, ao versar no artigo 1.216 das alterações exigidas pelo dono da obra na confecção do objeto do contrato, guarda evidente semelhança com a codificação brasileira, pois determina que o empreiteiro sofrerá a redução no pagamento do valor entabulado quando por força das modificações introduzidas pelo dono da obra vierem a diminuir seus custos com material ou mão de obra (art. $1.216,3)$.

Destaca-se também no Código Civil Português a tutela prestada pelo artigo 1.216, 2, que discorre sobre o direito facultado ao empreiteiro de ter uma ampliação no preço estipulado, majoração esta que corresponderá ao acréscimo nas despesas com materiais e mão de obra decorrentes das alterações no projeto exigidas pelo dono da obra.

Ao prosseguir com a ordem cronológica proposta, atingimos o artigo 621 do Código Civil Brasileiro, que se presta a resguardar indiretamente o direito autoral inerente ao autor do projeto técnico, pois pró́be que o dono da obra efetue modificações no projeto desenvolvido, essas 
que serão facultadas apenas em situações excepcionadas pelo caput do artigo 621.

Todavia, em complementação ao que fora tratado no caput do artigo 621, importante destacar que o parágrafo único do dispositivo em análise estabelece que pequenas alterações, desde que preservadas a unidade estética da obra projetada não serão reputadas como modificação do projeto.

Insta salientar que as legislações elencadas a título de estudo comparado não apresentam artigo com função idêntica ao ora analisado, contudo, observa-se que a legislação mexicana reserva diversos dispositivos com o escopo de preservar os direitos do profissional responsável pelo projeto do objeto contratual.

Cumpre esclarecer que a tutela prestada pela legislação mexicana justifica-se através da análise dos artigos 2.620, 2.621, 2.622 e 2.623 do Código Civil Mexicano, dispositivos estes que se prestam a regulamentar as hipóteses em que terá o autor do projeto direito a remuneração, bem como sobre a possibilidade de existir concorrência entre diversos projetistas, dentre outras disposições.

Sanados os debates e o estudo comparado em relação ao artigo 621 do Código Civil Brasileiro, cumpre discorrer sobre o dispositivo subsequente (art. 622), que acaba por limitar a responsabilidade do autor do projeto por possíveis danos, desde que não seja o responsável pela direção ou fiscalização da obra; logo, dispõe sobre a hipótese da confecção da obra ter sido transmitida a terceiro, ocasião em que a responsabilidade do projetista estará restrita aos danos provenientes de defeitos arrolados no caput e parágrafo único do artigo 618 do Código Civil.

Por sua vez, o artigo 623 do Código Civil Brasileiro prevê a hipótese de rescisão unilateral do contrato de empreitada por parte do dono da obra, desde que ocorra a devida indenização do empreiteiro pelos gastos que despendeu até o momento da rescisão, cabendo inclusive em certos casos, ressarcimento em relação aos lucros que poderiam ser auferidos com o término da edificação do objeto contratado.

Do ponto de vista do direito comparado, o artigo 623 guarda semelhanças com as legislações objeto de nossa análise comparada, pois o Código Civil Argentino em seu artigo 1.261 também prevê a faculdade do dono da obra desistir de sua execução, desde que indenize o empreiteiro. 
Além do mais, necessário se faz declarar que a hipótese supracitada também foi prevista pela norma mexicana através de seus dispositivos 2.635 e 2.636, bem como por seu artigo 2.637, que, ao complementar as previsões anteriores, estabelece que uma vez indenizado o empreiteiro o dono da obra estará livre para dar prosseguimento ao objeto do contrato de empreitada através da contratação de outras pessoas aptas a atingir os objetivos almejados.

Ainda no tocante à possibilidade de rescisão unilateral do contrato por vontade do dono da obra, destacamos que o artigo 1.229 do Código Civil Português também apresenta tal previsão.

Vencidas as questões inerentes às hipóteses de cessação e rescisão unilateral do contrato, inicia-se o estudo dos casos em que o empreiteiro poderá suspender a obra (art. 625, incisos I, II e III), sem deixar de olvidar que, se a suspensão descrita ocorrer sem justa causa, o empreiteiro responderá por perdas e danos, de acordo com o que estipula o artigo 624 do Código Civil Brasileiro.

Importante ressaltar que o inciso I do artigo 625 da norma brasileira determina que o empreiteiro poderá suspender a obra por culpa do dono, ou ainda, por motivo de força maior, dispositivo este que se assemelha à previsão fornecida pelo artigo 2.639 do Código Civil Mexicano, que discorre sobre as possibilidades em que a empreitada será suspensa por algum motivo que independa da vontade do empreiteiro.

Quanto ao inciso II do artigo 625, este prevê que o empreiteiro suspenderá a obra quando emanar no curso do contrato dificuldades imprevisíveis de execução decorrentes de causas geológicas ou hídricas, ou outras semelhantes, que venham a tornar a empreitada excessivamente onerosa, e o dono da obra se opuser ao reajustamento do preço.

Insta salientar que a previsão acima abordada pode ser observada do ponto de vista do direito comparado na legislação portuguesa, vez que o Código Civil Português no artigo 1.215, 2 apresenta uma hipótese de extinção do contrato caracterizada pela onerosidade excessiva, que no caso em debate, ocorrerá quando o preço relacionado ao contrato for majorado em patamar superior a vinte por cento, circunstância que facultará ao empreiteiro denunciar o contrato.

Com o escopo de finalizar a análise comparativa do artigo 625 do Código Civil, passaremos a interpretar as previsões fornecidas por seu inciso III, que determina que o empreiteiro poderá suspender a obra quando as modificações no projeto exigidas pelo dono da obra, forem 
desproporcionais ao projeto aprovado, ainda que o dono esteja disposto a arcar com a parte extraordinária da remuneração.

O inciso acima analisado também se apresenta como relevante para as legislações estrangeiras, já que o Código Civil Argentino em seu artigo 1.267, de forma expressa, declara que o contrato de empreitada poderá ser resolvido pelo empreiteiro quando sobrevier alguma impossibilidade de se fazer ou concluir o objeto do contrato, circunstância que se revela similar à prevista pelo inciso III do artigo 625, vez que podemos englobar no dispositivo argentino a hipótese da impossibilidade ter sido proveniente de modificações no projeto realizadas pelo próprio dono da obra.

Por fim, é mister discorrer sobre a tutela fornecida pelo artigo 626 do Código Civil Brasileiro, que determina que o contrato de empreitada não se presume intuitu personae, versando ainda indiretamente sobre o instituto jurídico da subempreitada, que se caracteriza quando um empreiteiro subroga a responsabilidade de entregar a obra de acordo com as especificações e na data de entrega prevista a outrem.

Entretanto, é dever tornar claro que apesar de não existir a presunção supracitada, as partes poderão ajustar previamente em contrato as ocasiões e circunstâncias em que as qualidades pessoais do empreiteiro deverão prevalecer, situação específica que poderá levar à extinção do contrato de empreitada em caso de morte do empreiteiro.

Com relação ao tema, relevantes se demonstram os ensinamentos prestados por Orlando Gomes, que ao discorrer sobre a matéria leciona:

não há proibição de subempreitar, até porque, ordinariamente, $\mathrm{o}$ empreiteiro não se compromete a executar pessoalmente a obra. Em certos casos é, entretanto, inadmissível. Não é lícito subempreitar obra encomendada em atenção às qualidades pessoais do empreiteiro. Não cabe, por outras palavras, nas empreitadas intuitu personae. ${ }^{402}$

Ainda no tocante à matéria merece destacar que mesmo ocorrendo a subempreitada, o empreiteiro que figurou no polo passivo do 
contrato, responderá pela má execução da obra, responsabilizando-se perante terceiros e pelos danos que causar, bem como pelos causados por seus empregados ou prepostos.

A informação acima prestada se faz presente nas lições ofertadas por Sérgio Cavalieri Filho, que ao discorrer sobre o tema leciona que:

a principal obrigação do empreiteiro é executar a obra, tal como lhe foi encomendada. Dependendo da natureza da prestação, terá que executar o trabalho pessoalmente ou por seus prepostos, mas sempre sob sua direção. ${ }^{403}$

Superado o estudo da codificação brasileira acerca das previsões fornecidas pelo artigo 626, tem início a análise o tema sob a égide do direito comparado, circunstância que nos obriga a destacar que o Código Civil Argentino se assemelha ao brasileiro, vez que a legislação argentina em seu artigo 1.260 estabelece que os herdeiros do empreiteiro poderão continuar com a edificação do objeto do contrato salvo acordo em contrário previsto no contrato original.

Em complementação, o Código Civil Argentino prevê o supracitado artigo 1.260 que o contrato de empreitada poderá ser extinto com o falecimento do empreiteiro, ocasião em que os valores proporcionais aos serviços que já foram desenvolvidos deverão ser adimplidos em benefício de seus herdeiros, portanto, a legislação argentina apresenta-se semelhante à brasileira, pois permite a subempreitada, bem como que o contrato venha a ser diretamente relacionado à figura do empreiteiro para sua conclusão, ocasião em que adotará o caráter intuitu personae.

Com relação à análise comparativa proposta, merece destacar ainda que a legislação portuguesa também se demonstra favorável ao posicionamento adotado pelas normas brasileira e argentina, pois o Código Civil Português em seu artigo 1.213 estabelece a possibilidade de ser admitida a subempreitada, bem como do empreiteiro exercer o direito de regresso em face do subempreiteiro (art. 1.226).

Relevante também se faz destacar sobre a codificação portuguesa, que esta declara expressamente em seu artigo 1.230, 1, que a morte ou

403 CAVALIERI FILHO, Sérgio. Programa de responsabilidade civil. $6^{\text {a }}$. ed. rev., aum. e atual. São Paulo: Malheiros, 2005, p.366. 
incapacidade do empreiteiro não colocará fim ao contrato de empreitada, excetuando-se a hipótese de terem sido ressalvadas em contrato as qualidades inerentes ao empreiteiro, circunstância que tornaria a relação jurídica intuitu personae, fato que evidencia outra importante semelhança existente entre a norma brasileira e a portuguesa.

Por sua vez, quanto ao Código Civil Mexicano, este também se apresenta de modo semelhante às demais legislações que foram alvo de nosso estudo comparado.

A declaração acima se revela através da interpretação dos artigos 2.633 e 2.638. Cumpre esclarecer que o artigo 2.633 acaba por permitir a subempreitada sob a égide da legislação mexicana, pois apesar de prever que o empreiteiro será o encarregado pela entrega do objeto contratado, estipula que as partes poderão pactuar algo em contrário no instrumento contratual.

Saliente-se outrossim, que o artigo 2.638 do Código Civil Mexicano estabelece que o falecimento do empreiteiro durante a relação jurídica poderá colocar fim ao contrato, circunstância que obrigará o dono da obra a indenizar os herdeiros pelos trabalhos realizados, ou seja, a extinção do contrato em caso de falecimento do empreiteiro ficará a cargo dos contratantes, que analisarão a possibilidade do objeto do contrato ser concluído por pessoas que não o próprio empreiteiro falecido.

Sendo assim, restaram analisadas, de maneira pontual, as principais características vinculadas ao contrato de empreitada, análise esta que se reportou de modo objetivo às legislações eleitas com o escopo de viabilizar o estudo comparado almejado pelo presente trabalho, que se revelou apto a demonstrar as principais semelhanças e diferenças inerentes às codificações objeto de comparação.

\section{CONSIDERAÇÕES FINAIS}

O contrato de empreitada, com suas origens no direito romano, teve sua evolução e disseminação em diversos países. Tem por objeto a obra e não o trabalho, consistindo em obrigação de resultado assumida pelo contratado, isto é, a obra como atividade fim e não meio, podendo ser realizada pessoalmente ou por terceiros.

Com a finalidade de realizar o estudo comparado sobre o referido instituto, analisaram-se as legislações de Portugal, Brasil, Argentina e 
México. Após a análise dos diversos conceitos expostos, é possível afirmar que o contrato de empreitada possui como características o fato de ser bilateral, oneroso, consensual e, como regra, comutativo, pois eventualmente pode vir a ser aleatório.

Ademais, sob a perspectiva do direito comparado verificou-se que hodiernamente o tratamento dado ao instituto na Argentina, excluiu a expressão locação de obra, coadunando-se com os demais ordenamentos.

Merece destacar que as principais características vinculadas ao contrato de empreitada foram as seguintes:

I. No que tange às suas características básicas, essas possuem mínimas diferenças entre as codificações objeto de comparação. Apesar de distinções no vernáculo, em todas as legislações objeto de análise, existe a figura do empreiteiro, que no caso é aquele que executará a obra, cabendo a ele sua fiscalização e a responsabilidade pelos riscos dela provenientes. Além do mais, em todas as codificações verifica-se que as partes envolvidas no contrato diferem apenas na denominação;

II. Sobre as diferenças entre os ordenamentos, a regra nacional é que seja adotada a modalidade de lavor, ao passo que nas legislações portuguesa (art. 1.210,1) e mexicana (art. 2.616) os materiais e utensílios necessários à execução da obra deverão ser fornecidos pelo empreiteiro (salvo convenção ou uso em contrário) ao passo que no Código Civil Argentino será facultado às partes contratantes optar pela modalidade que melhor lhes convir, porém, se nada for acordado, presumir-se-á que será fornecedor dos materiais o empreiteiro;

III. Quanto ao objeto do contrato, este é semelhante em todos os países: não envolverá apenas as edificações relacionadas a bens imóveis, mas também as criações artísticas, intelectuais e de bens móveis;

IV. No que se refere à responsabilidade civil prevista pelas legislações mencionadas, cumpre mencionar que os riscos até a entrega da obra correrão por conta do empreiteiro, exceto se o dono da obra estiver em mora quanto ao recebimento do objeto da contratação, previsão que se assemelha a legislação argentina, apesar de estender a responsabilidade, de forma concorrente ao mandatário, ao subempreiteiro, ao projetista, ao diretor da obra e qualquer outro profissional ligado ao empreiteiro pelo referido contrato;

V. A remuneração do contrato de empreitada consiste no adimplemento da contraprestação pelo dono da obra, isto é, deverá ocorrer quando da entrega do objeto do contrato de empreitada, disposição esta 
que não é expressamente arrolada por nossa legislação, ao contrário do que ocorre nas codificações mexicana (art. 2.625) e portuguesa (art. $1.211,2)$;

VI. Sobre a existência em nosso ordenamento da possibilidade do dono da obra receber o objeto do contrato com abatimento no valor a ser pago ao empreiteiro, ao invés de simplesmente rejeitá-lo, o Código Civil Português faculta o direito de o dono da obra recusar o objeto, sem prejuízo de indenização por força dos prejuízos suportados. Ainda, o mesmo código estipula os prazos de caducidade para o exercício dos direitos de eliminação dos defeitos, de redução do preço ajustado e da resolução ou indenização vinculadas ao contrato de empreitada, estipulando inclusive que na hipótese dos defeitos serem desconhecidos pelo dono da obra, o prazo de caducidade contar-se-á a partir da denúncia do defeito;

VII. Quanto à tutela prestada pelo Código Civil Brasileiro com relação a obras de vulto, este determina a responsabilidade inerente ao empreiteiro de responder pelo prazo irredutível de 05 (cinco) anos pela segurança e solidez, bem como em razão dos materiais empregados na empreitada, sendo que o prazo quinquenal é imperativo e de ordem pública, não podendo o empreiteiro dele se eximir ou reduzir sua amplitude. Por sua vez, o Código Civil Argentino, determina que o prazo de garantia perdurará por 10 (dez) anos;

VIII. A legislação mexicana não é taxativa como a brasileira e a argentina, que estabeleceram prazos fixos e amplos para obras consideradas de vulto; de seu turno, a codificação portuguesa de forma semelhante à brasileira preceitua que a garantia vinculada às obras de vulto será de 05 (cinco) anos, arrolando, contudo, que poderá existir prazo de garantia a ser convencionado entre os contratantes;

IX. Quanto à contagem do lapso temporal acima exposto, o legislador português estabeleceu que seu início ocorrerá a partir da entrega do bem. Em complementação, no tocante ao prazo para a denúncia dos defeitos e vícios, essa deverá ser efetuada dentro do prazo de 01 (um) ano e a indenização deverá ser pleiteada no ano seguinte à realização da denúncia (art. 1.225, 2). O mesmo código faculta ao empreiteiro o exercício do direito de regresso em face do subempreiteiro, faculdade que caducará se não ocorrer a comunicação da denúncia pelo empreiteiro ao subempreiteiro dentro do prazo de 30 (trinta) dias contados de sua recepção (art. 1.226); 
X. Em caso de reajuste no preço, o Código Civil Mexicano estabelece a impossibilidade de reajustar a remuneração da empreitada pactuada por preço determinado; mesma ressalva é abordada pela norma brasileira, pois determina que a modificação do preço poderá ocorrer desde que as alterações no projeto tenham sido resultantes de instruções escritas pelo dono da obra, essas que deverão inclusive relacionar-se expressamente à questão do preço a ser reajustado. Nesse diapasão, o Código Civil Português estabelece que nas hipóteses em que for fixado preço determinado para a empreitada e não tiver ocorrido por escrito a alteração do projeto estipulando o reajuste do preço, o empreiteiro apenas poderá requerer indenização equivalente ao enriquecimento contraído pelo dono da obra.

A revisão do preço em nosso código observa que será adimplido pelo dono da obra todas as vezes em que ocorrer a redução no preço do material ou da mão de obra superior a 1/10 (um décimo) do preço ajustado. Evidente semelhança guarda a legislação portuguesa, pois determina que o empreiteiro sofrerá a redução no pagamento do valor entabulado quando por força das modificações introduzidas pelo dono da obra vierem a diminuir seus custos com material ou mão de obra (art. 1.216, 3);

XI. Sobre o direito autoral inerente ao autor do projeto técnico, que proíbe que o dono da obra efetue modificações no projeto desenvolvido, a norma estabelece pequenas alterações, desde que preservadas a unidade estética da obra projetada, não serão reputadas como modificação do projeto. De seu turno, a legislação mexicana reserva diversos dispositivos com o escopo de preservar os direitos do profissional responsável pelo projeto do objeto contratual;

XII. No que se refere à hipótese de rescisão unilateral do contrato de empreitada por parte do dono da obra é verificada sua viabilidade (desde que ocorra a devida indenização do empreiteiro pelos gastos que despendeu até o momento da rescisão, cabendo inclusive ressarcimento em relação aos lucros que poderiam ser auferidos com o término da edificação do objeto contratado);

XIII. Sobre casos em que o empreiteiro poderá suspender a obra é importante mencionar que o Código Civil pátrio determina que o empreiteiro poderá suspender a obra por culpa do dono, ou ainda, por motivo de força maior, dispositivo este que se assemelha à previsão do Código Civil Mexicano, que discorre sobre as possibilidades em que a empreitada 
será suspensa por algum motivo que independa da vontade do empreiteiro.

Nos casos da empreitada se tornar excessivamente onerosa e o dono da obra se opor ao reajustamento do preço, o Código Civil Português apresenta uma hipótese de extinção do contrato caracterizada pela onerosidade excessiva, que no caso em debate ocorrerá quando o preço relacionado ao contrato for majorado em patamar superior a vinte por cento, circunstância que facultará ao empreiteiro denunciar o contrato;

XIV. O Código Civil Argentino se assemelha ao brasileiro ao permitir a subempreitada, bem como prevê que na hipótese de ocorrer o falecimento do empreiteiro, poderá haver ou não a extinção do vínculo contratual, sendo que tudo dependerá se o contrato foi pactuado em caráter intuitu personae. De forma semelhante estabelece o Código Civil Português a possibilidade de ser admitida a subempreitada, bem como do empreiteiro exercer o direito de regresso em face do subempreiteiro (art. 1.226). A mesma legislação pontua que a morte ou incapacidade do empreiteiro não colocará fim ao contrato de empreitada (salvo terem sido ressalvadas em contrato as qualidades inerentes ao empreiteiro, circunstância que tornaria a relação jurídica intuitu personae, fato que evidencia outra importante semelhança existente entre a norma brasileira e a portuguesa). Paralelamente, o Código Civil Mexicano estabelece que o falecimento do empreiteiro durante a relação jurídica poderá colocar fim ao contrato, circunstância que obrigará o dono da obra a indenizar os herdeiros pelos trabalhos realizados, ou seja, a extinção do contrato em caso de falecimento do empreiteiro ficará a cargo dos contratantes, que analisarão a possibilidade do objeto do contrato ser concluído por pessoas que não o próprio empreiteiro falecido.

\section{REFERÊNCIAS BIBLIOGRÁFICAS}

CARAMELO, Gustavo; PICASSO, Sebastián ; HERRERA, Marisa. Código Civil y Comercial de la Nación Comentado. $1^{\mathrm{a}}$ ed. Ciudad Autónoma de Buenos Aires : Infojus, 2015.

CAVALIERI FILHO, Sérgio. Programa de responsabilidade civil. $6^{\mathrm{a}}$. ed. rev., aum. e atual. São Paulo: Malheiros, 2005. 
DINIZ, Maria Helena. Curso de direito civil brasileiro: responsabilidade civil, $7 \mathrm{v}, 20^{\mathrm{a}}$. ed., rev. e atual. São Paulo: Saraiva, 2006.

FARIAS, Cristiano Chaves de \& ROSENVALD, Nelson. Contratos teoria geral e contratos em espécie. 2 ed. Salvador: Jus Podivum, 2012.

FIUZA, César. Direito civil: curso completo. $7^{\mathrm{a}}$. ed., rev., atual. e ampl. de acordo com o código civil de 2002. Belo Horizonte: Del Rey, 2003.

GOMES, Orlando. Contratos. 26 $6^{\mathrm{a}}$. ed. Rio de Janeiro: Forense, 2008.

GONÇALVES, Carlos Roberto. Responsabilidade civil. $8^{\mathrm{a}}$. ed., rev. de acordo com o novo Código Civil. São Paulo: Saraiva, 2003.

. Direito civil brasileiro: contratos e atos unilaterais. 4. ed., rev. e atual. São Paulo: Saraiva, 2007.

, Direito Civil Esquematizado, 2; coordenador Pedro Lenza - 2 ed. Rev. E atual. São Paulo: Saraiva, 2014

PEREIRA, Caio Mário da Silva. Instituições de direito civil: contratos, $6 \mathrm{v}, 12^{\mathrm{a}}$. ed., rev. e atual. Rio de Janeiro: Forense, 2007.

$<$ http://www.codigocivilonline.com.ar/> Acesso realizado em: 02/04/2015.

$<$ http://www.confap.pt/docs/codcivil.PDF $>$ Acesso realizado em: $02 / 11 / 2014$.

< http://www.solon.org/Statutes/Mexico/Spanish/cc-intro.html> Acesso realizado em: 02/11/2014.

http://www.infoleg.gob.ar/infolegInternet/anexos/235000239999/235975/ norma.htm\#22> Acesso realizado em: 28/03/2016. 
